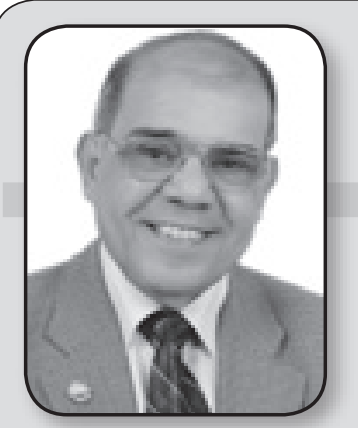

\section{أول الكالم}

ثورة الببـانات ..

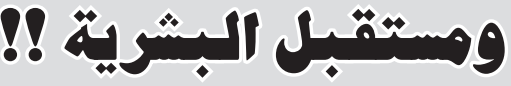

لعلنا نشهد الان.. ومن بداية العام الذى نعيشه فى ظل ثلث تورة

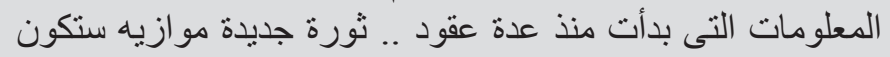

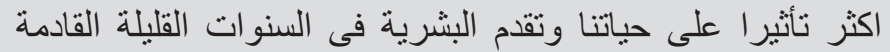

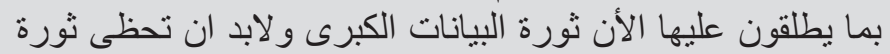

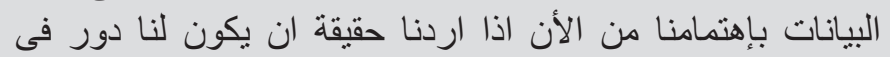

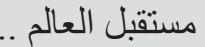
وحتى ندرك أهمية البيانات .لابد ان ندرك أنه.يوجد في العالم

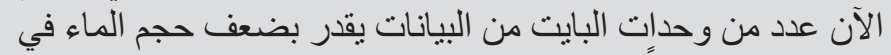

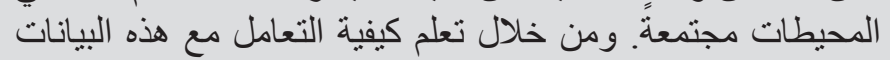

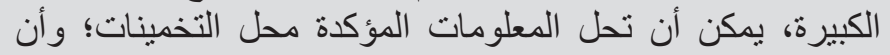

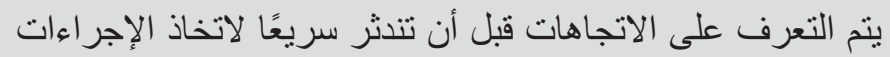
الضرورية اللازمة اولمو اجهة الأزمات التهات.

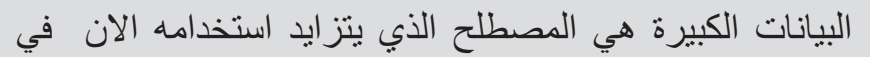

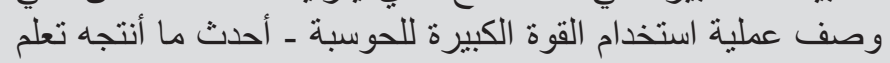

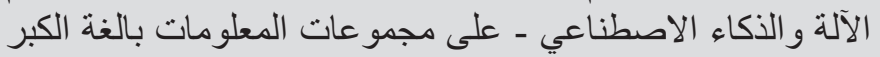

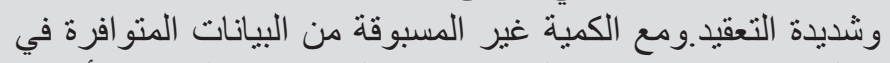

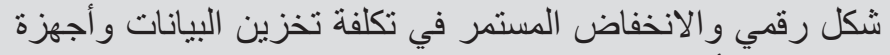

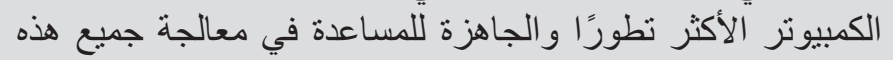

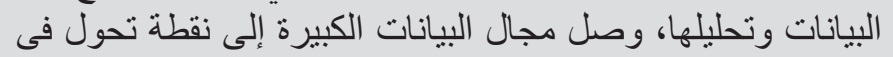

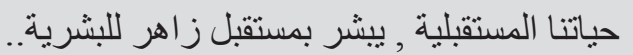

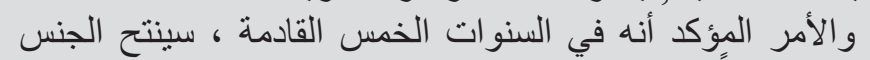

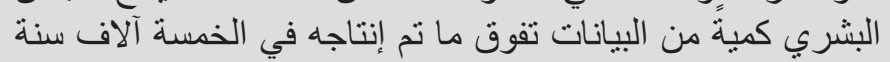

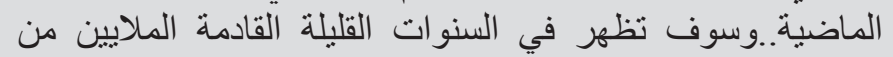

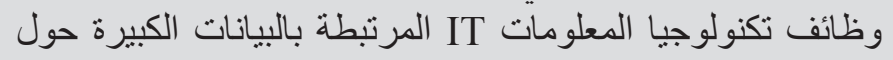

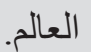
عالم البيانات فى الفترة القادمة ستشهد سوقا عالمية محمومة

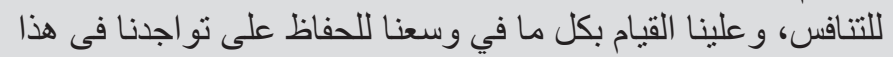

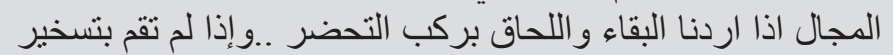

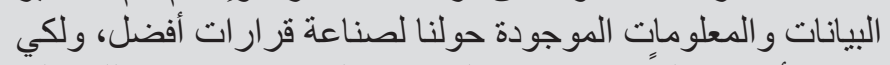

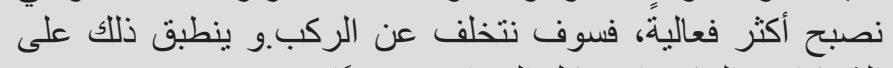
الشركات و الحكومات وكل فل المجالات تقريبًا.

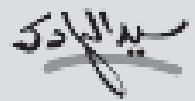

sayedalhady@gmail.com

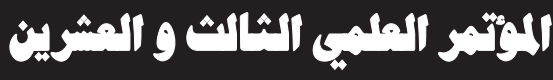

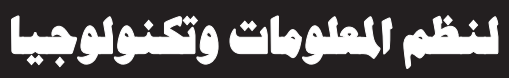 \\ Ja}

\section{إدارة تكنولوجيا المملوهات}

Managing Information

Technology

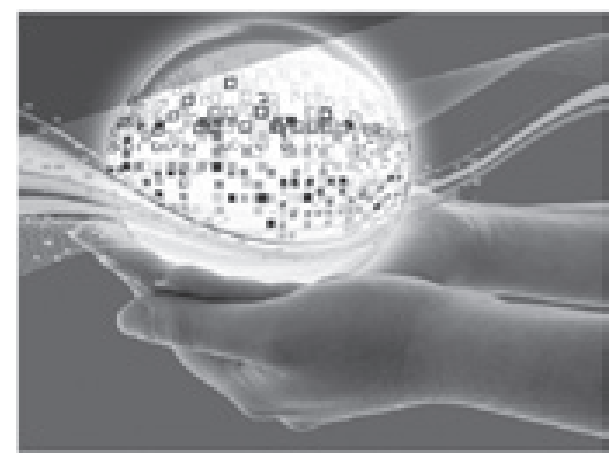

V O

\section{تقريز ختام وتوصيات الموثتم الملمي الثانى والمثرين لنظمي المعلموهات وتكنولوجيا الماسبات}

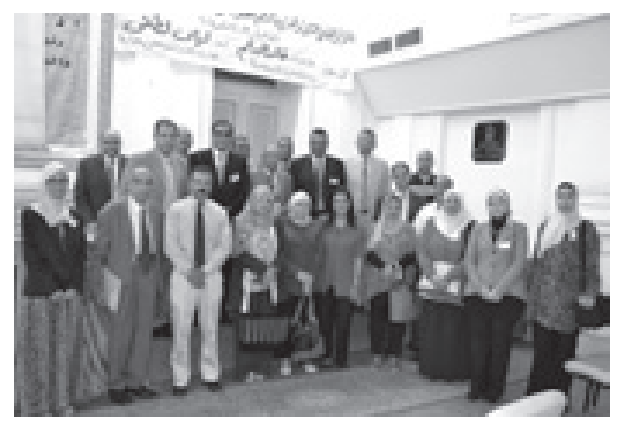

"ومثاركة المهرفة ونقمها وإدارتها لتدميم الإبداع والتنمية الوطنيةهة

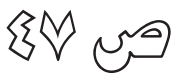

